\title{
Bioaccumulation of Metals in Fish from Sarikum Lake
}

\author{
Levent BAT, Öztekin Yardım, Ayşah Öztekin, Fatih Şahin \\ Sinop University Fisheries Faculty, Department of Hydrobiology, 57000 Sinop, Turkey \\ E-mail: leventbat@gmail.com
}

Received: August 1, 2017 Accepted: August 22, 2018 Published: August 30, 2018

doi:10.5296/ast.v7i1.13456 URL: https://doi.org/10.5296/ast.v7i1.13456

\begin{abstract}
Concentrations of five heavy metals $(\mathrm{Hg}, \mathrm{Cd}, \mathrm{Pb}, \mathrm{Cu}$ and $\mathrm{Zn})$ in edible tissues of four fish species (Cyprinus carpio, Platichthys flesus, Liza aurata, Mugil cephalus) collected from Natural Reserve Area called Sarikum Lake were determined by ICP-MS (Agilent 7700x). The order of heavy metal concentration was observed as: $\mathrm{Zn}>\mathrm{Cu}>\mathrm{Hg}>\mathrm{Pb}>\mathrm{Cd}$. The heavy metal levels were species specific and significantly different. The highest concentrations of $\mathrm{Hg}, \mathrm{Cd}$ and $\mathrm{Zn}$ were found in flathead grey mullet, European flounder and common carp, respectively. The higher concentrations of $\mathrm{Pb}$ and $\mathrm{Cu}$ are present in golden grey mullet. The concentrations of $\mathrm{Cd}$ are in range of 0.019-0.027 $\mu \mathrm{g} \mathrm{g}^{-1}$ in common carp, 0.028-0.040 $\mu \mathrm{g} \mathrm{g}^{-1}$ in European flounder, $0.020-0.034 \mu \mathrm{g} \mathrm{g}^{-1}$ in golden grey mullet and $0.16-0.27 \mu \mathrm{g} \mathrm{g}^{-1}$ in flathead grey mullet tissues. Concentration of $\mathrm{Cd}$ in $M$. cephalus was limit value and precautions need to be taken in order to prevent future heavy metal contamination, but other metals were lower than those in certified values.
\end{abstract}

Keywords: Cyprinus carpio, Platichthys flesus, Liza aurata, Mugil cephalus, Sarikum Lake

\section{Introduction}

Heavy metals discharged into the aquatic environment can damage both biodiversity and ecosystem, owing to their hazards and accumulative tendency in the biota. Even though protective measures have been taken to minimize the input of pollutants into sea, rivers, lakes and estuaries, accumulation in the aquatic ecosystems have been faced still today. Anthropogenic activities can create a potential source of heavy metal pollution in the aquatic ecosystems. Metals like zinc and copper are required for metabolic activities in organisms, whereas cadmium, mercury and lead show toxicity, thence these metals have been involved in the legislations for hazardous metals (EC, 2006; TFC, 2009).

Heavy metals eventually enter in aquatic ecosystems and their bioaccumulation and magnification can cause physiological and morphological alterations in aquatic animals especially fish. Sarikum Lake is a natural aquatic ecosystem. In 1987, Sarikum area has been officially registered as "Natural Reserve Area" by the abrogated Ministry of Forestry. In 1991, Sarikum Lake and its environment were registered as "Nature Protection Area". It is a 785 ha 


\section{MInstitute Macrothink $_{\text {Int }}$}

complex ecosystem of sea, sand, freshwater lake, wetland, peatland, marshland and forest. Biodiversity of Sarikum Lake is high due to this complex ecosystem (Anonymous 1997; Yilmaz, 2005). In addition riparian vegetation develops well around the lake. The bottom structure is composed of clay. It is close to the sea and it connects with the sea with a natural water channel. This situation makes the lake a proper living area for birds and other aquatic organisms (Yardim et al., 2008; Sivaci et al., 2008) including fish (Yardim, 2017). The aim of the present study is to determine heavy metal amounts in Cyprinus carpio Linnaeus, 1758 belonging to the Cyprinidae family, Platichthys flesus (Linnaeus, 1758) belonging to the Pleuronectidae family, Liza aurata (Risso, 1810) and Mugil cephalus Linnaeus, 1758 belonging to the Mugilidae family from Sarikum Lake.

\section{Material and Methods}

The present study was carried out in 2011. Trammel net, cover net and seine were mostly used in catching the fish species from Sarikum Lake (Figure 1). Five individuals were taken from each species and were dissected in order to obtain muscle tissues that were mixed homogeneously and immediately frozen and stored at $-21{ }^{\circ} \mathrm{C}$ till metal analyses. For determination of heavy metal amounts in fish samples, about $1 \mathrm{~g}$ of fish tissues was digested with Suprapur® nitric acid in a microwave closed system (Milestone Systems, Start D 260) for analysis. Samples were diluted to a final volume of $25 \mathrm{ml}$ with double deionized water after digestion. At the same time, a blank trial was carried out. After digestion, $\mathrm{Hg}, \mathrm{Cd}, \mathrm{Pb}$, $\mathrm{Cu}$ and $\mathrm{Zn}$ concentrations of muscle samples were analyzed by ICP-MS (Agilent 7700x) and TORT-3 lobster hepatopancreas reference material for trace metals was used to determine the reliability of the heavy metal analysis. Heavy metals in fish tissues were expressed as microgram of metal per gram of wet weight sample.

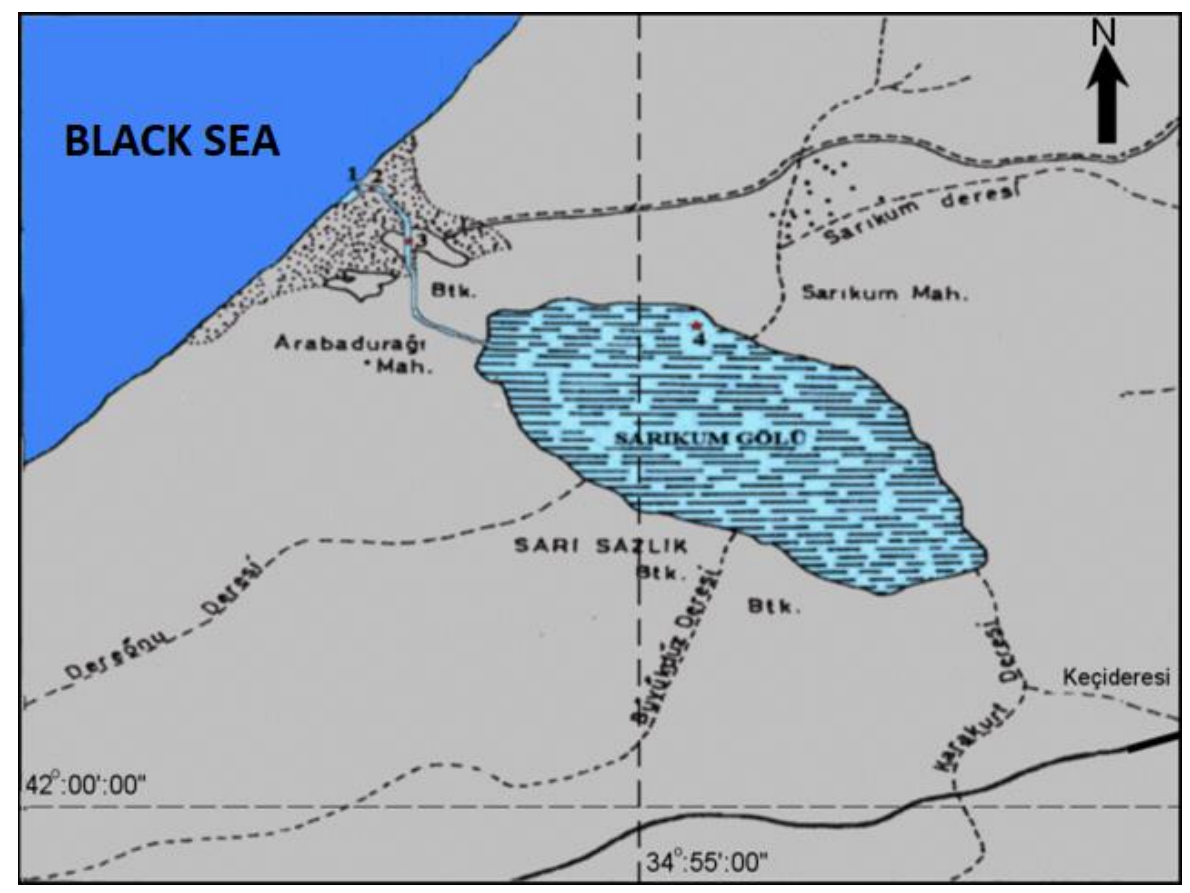

Figure 1. Sarikum Lake 


\section{Results}

The certified and the analytical values with the Relative Standard Deviation percentage were always less than $10 \%$. The contents of $\mathrm{Hg}, \mathrm{Cd}, \mathrm{Pb}, \mathrm{Cu}$ and $\mathrm{Zn}$ in edible tissues of examined samples from the Sarikum Lake were below the permissible levels. However, the results show significant difference $(\mathrm{p}<0.05)$ between the muscle tissues of various species. Metal levels in the edible tissues of C. carpio, P. flesus, L. aurata and M. cephalus from Sarikum Lake were given in Figures 2-6. The order of mean metal amounts deposited in muscles of species from Sarikum Lake is $\mathrm{Zn}>\mathrm{Cu}>\mathrm{Hg}>\mathrm{Pb}>\mathrm{Cd}$. The highest concentrations of $\mathrm{Hg}, \mathrm{Cd}$ and $\mathrm{Zn}$ were found in flathead grey mullet, European flounder and common carp, respectively. The higher concentrations of $\mathrm{Pb}$ and $\mathrm{Cu}$ are present in golden grey mullet. The concentrations of $\mathrm{Cd}$ are in range of $0.019-0.027 \mu \mathrm{g} \mathrm{g}^{-1}$ in common carp, 0.028-0.040 $\mu \mathrm{g} \mathrm{g}^{-1}$ in European flounder, $0.020-0.034 \mu \mathrm{g} \mathrm{g}^{-1}$ in golden grey mullet and $0.16-0.27 \mu \mathrm{g} \mathrm{g}^{-1}$ in flathead grey mullet tissues.

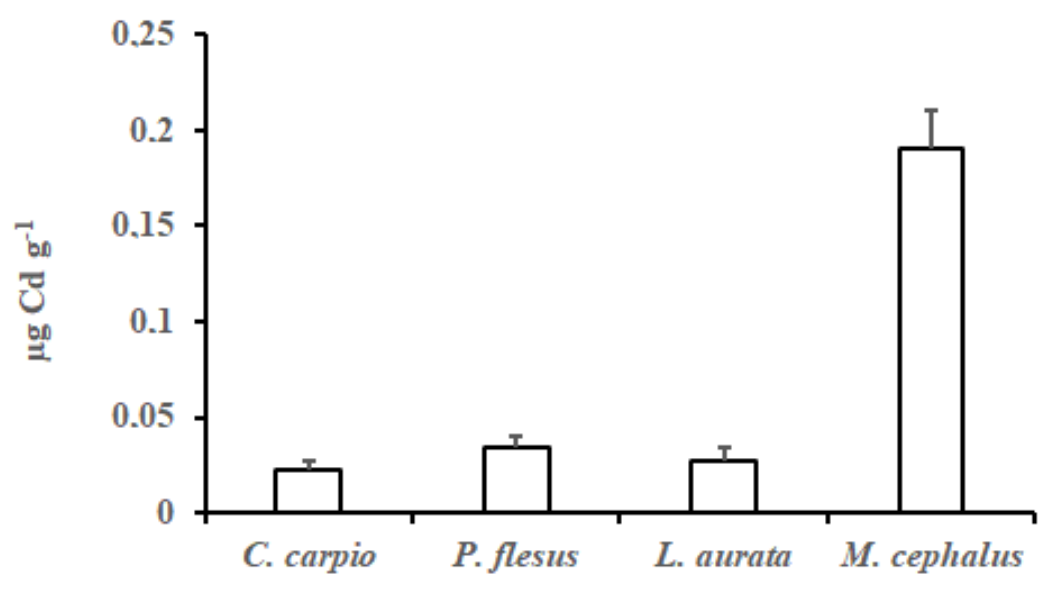

Figure 2. Mean levels and standard deviation of $\mathrm{Cd}\left(\mu \mathrm{g} \mathrm{g}^{-1}\right.$ wet wt.) found in edible tissues of in C. carpio, P. flesus, L. aurata and M. cephalus from Sarikum Lake in 2011.

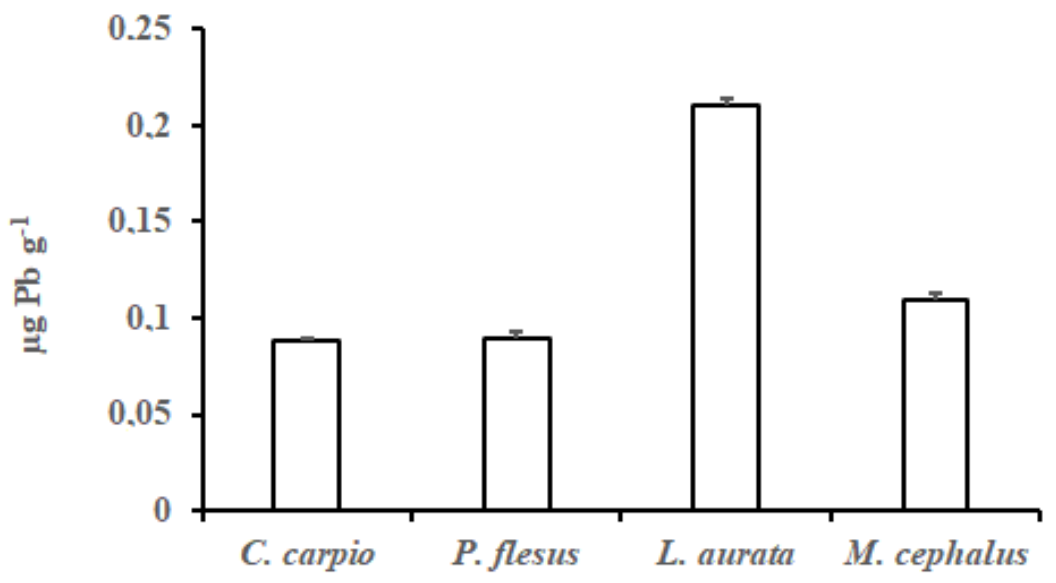

Figure 3. Mean levels and standard deviation of $\mathrm{Pb}\left(\mu \mathrm{g} \mathrm{g}{ }^{-1}\right.$ wet wt.) found in edible tissues of in C. carpio, P. flesus, L. aurata and M. cephalus from Sarikum Lake in 2011. 


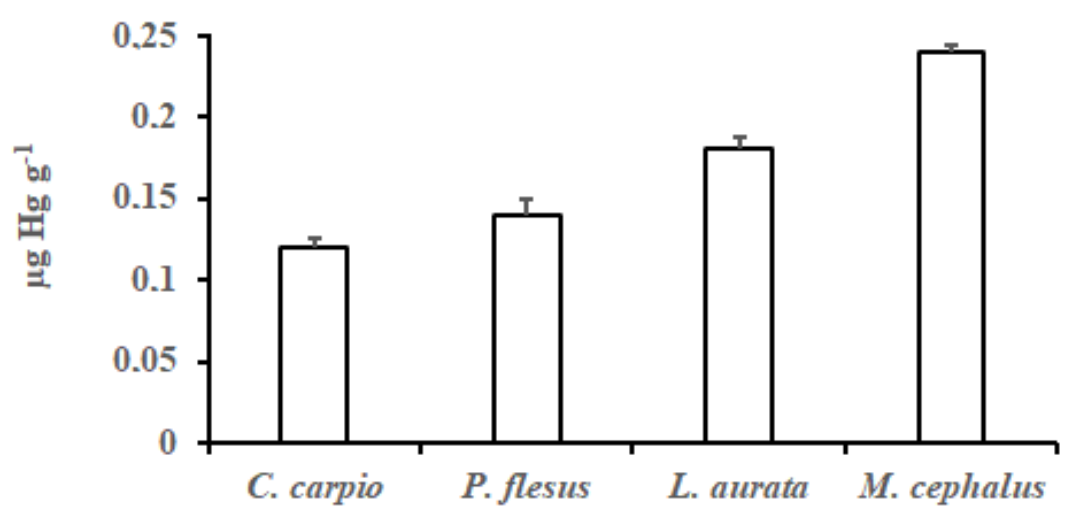

Figure 4. Mean levels and standard deviation of $\mathrm{Hg}$ ( $\mu \mathrm{g} \mathrm{g}^{-1}$ wet wt.) found in edible tissues of in C. carpio, P. flesus, L. aurata and M. cephalus from Sarikum Lake in 2011.

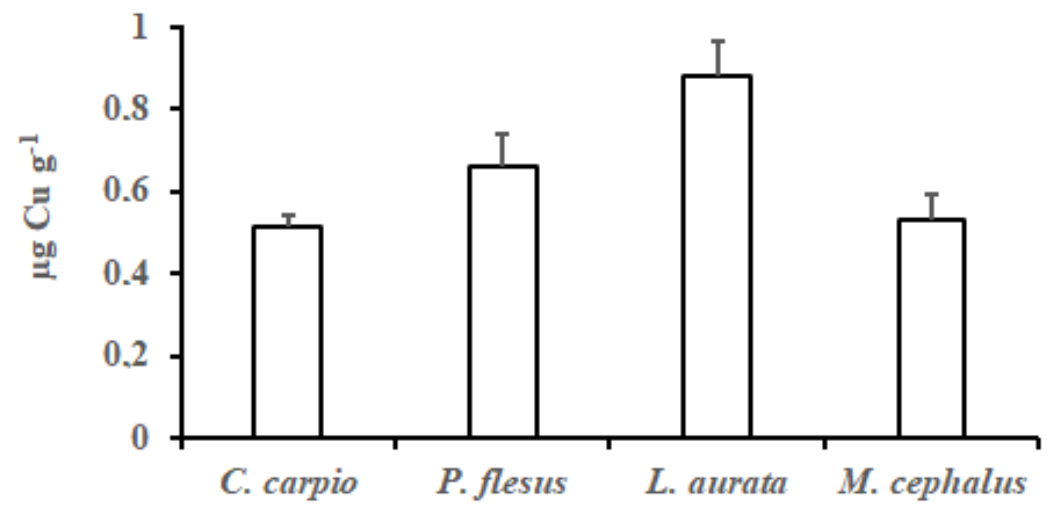

Figure 5. Mean levels and standard deviation of $\mathrm{Cu}\left(\mu \mathrm{g} \mathrm{g}{ }^{-1}\right.$ wet wt.) found in edible tissues of in C. carpio, P. flesus, L. aurata and M. cephalus from Sarikum Lake in 2011.

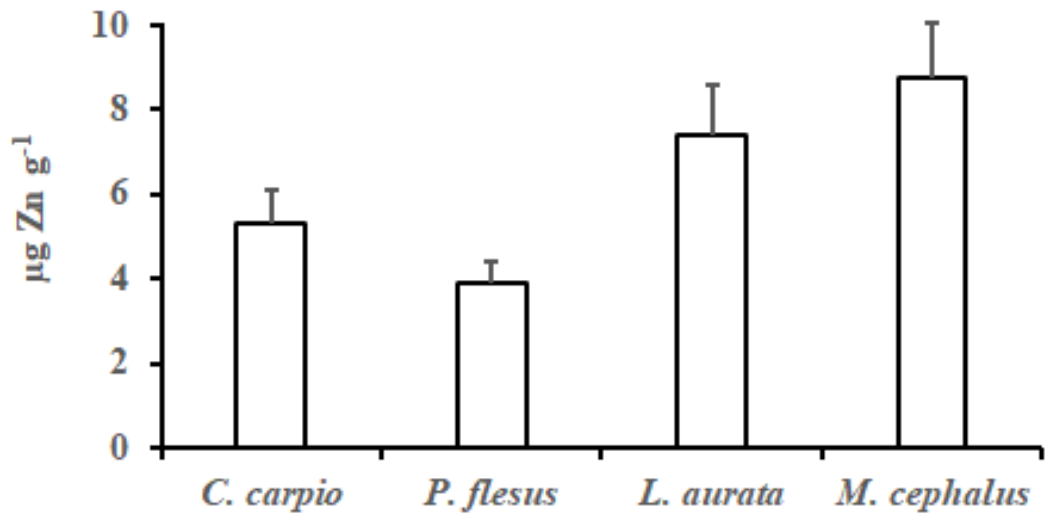

Figure 6. Mean levels and standard deviation of $\mathrm{Zn}\left(\mu \mathrm{g} \mathrm{g}^{-1}\right.$ wet wt.) found in edible tissues of in C. carpio, P. flesus, L. aurata and M. cephalus from Sarikum Lake in 2011.

\section{Discussion}

Heavy metals are present in nature at low levels and the increase of their levels shows the 
environmental pollution. The heavy metals levels were variously distribution in fish species. The values of metal levels in examined fish samples from the Sarikum Lake were below the limit of detection of the Commission Regulation and Turkish Food Codex (EC, 2006; TFC, 2009) except $\mathrm{Cd}$ in M. cephalus. The results show significant difference $(\mathrm{p}<0.05)$ between the edible tissues of these species, but also the highest deposition of $\mathrm{Cd}$ in muscle tissues of $M$. cephalus. When the levels of $\mathrm{Cd}$ were compared with other international regulations (Georgian Food Safety Rules, 2001; GAIN Report Russian Federation, 2006) for limit values in the muscles of fish, it can be seen that the Cd levels in flathead grey mullet tissues is not threats for human health. The Georgian Food Safety Rules (2001) and GAIN Report Russian Federation (2006) established the maximum levels of heavy metals in fish muscles $\left(0.2 \mu \mathrm{g} \mathrm{g}^{-1}\right.$ wet wt.) and only in flathead grey mullet muscle tissue $\mathrm{Cd}$ was detected in concentration close to proposed concentration. Moreover Sarikum Lake and its environment are Nature Protection Area and are not allowed fishing. Differences between the mean concentrations of studied heavy metals in the muscles of four fish species are closely connected with their feeding habits. The significant higher concentrations of $\mathrm{Cd}$ are present in $M$. cephalus that feeds on detritus, micro-algae and benthic organisms. Although $C$. carpio feeds on a variety of benthic organisms and plant material, P. flesus feeds on benthic fauna and L. aurata feeds on small benthic organisms, detritus, and occasionally on insects and plankton (Froese and Pauly, 2018), this heavy metal was accumulated in low concentration in muscles of those fish species. The presence of heavy metals in water, sediment and biota depends on also many environmental factors like influence of industry and other forms of pollution. Although there is no industrial activity in Sarikum Lake, the surplus of coastal litter in the region and microlitter in the water of Sarikum are remarkable (Öztekin and Bat, 2017). The Hg levels are detected low concentrations in all investigated species. $\mathrm{Hg}$ is non-essential metal for living organisms and its presence in fish tissues is limited. It is the one of the very toxic metals with tendency to bind to the sulfide group of proteins and deposits in muscles (Castro-Gonzalez and Mendez-Armenta, 2008) that can explain the highest concentration of $0.24 \pm 0.004 \mu \mathrm{g} \mathrm{g}^{-1}$ wet wt. in the muscles of $M$. cephalus followed by L. aurata $\left(0.18 \pm 0.008 \mu \mathrm{g} \mathrm{g}^{-1}\right.$ wet wt.). Similarly, the $\mathrm{Pb}$ levels are also below the maximum permitted concentrations of the edible tissues of fish proposed by Commission of the European Communities (EC) and Turkish Food Codex (TFC). Concentrations of heavy metals in fish samples vary and significantly depend on fish species. $\mathrm{Zn}$ is the highest content in all edible tissues of studied species from Sarikum Lake followed by $\mathrm{Cu}$. Differences between the mean levels of investigated metals in the edible tissues of four fish species are closely connected with their feeding habits.

In conclusion, the present study provides information about heavy metal contents in fish species from the Sarikum Lake. The analysis of the muscles of fish has shown heavy metal concentrations below levels of legislation, while maximum level of $\mathrm{Cd}$ in $M$. cephalus was limit value and precautions need to be taken in order to prevent future heavy metal contamination. Considering all these results, it is needed to monitor the presence of heavy metals as environmental contaminants in the future, thus ensuring a Good Ecological Status (GES) of Sarikum Lake, as well as providing the healthy ecosystem. 


\section{Acknowledgement}

This work was carried out at the Department of Hydrobiology, Fisheries Faculty, University of Sinop. A part of this study was presented as a poster with English abstract only in SEAB 2018, The $4^{\text {th }}$ International Symposium on EuroAsian Biodiversity, Kiev Ukraine.

\section{References}

Anonymous (1997). National Environmental Action Plan. Land Use and Management of Coastal Areas. State Planning Organization, 94 p. (in Turkish).

Castro-González, M.I., \& Méndez-Armenta, M. (2008). Heavy metals: Implications associated to fish consumption. Environmental Toxicology and Pharmacology, 26: 263-271. https://doi.org/10.1016/j.etap.2008.06.001

EC (COMMISSION REGULATION) (2006). Setting maximum levels for certain contaminants in foodstuffs, No 1881/2006 of 19 December 2006.

Froese, R. \& Pauly, D. Editors. 2018. FishBase. World Wide Web electronic publication. [Online] Available: www.fishbase.org

GAIN (Global Agriculture Information Network) Report. 2002. Russian Federation Sanitary/ Phytosanitary/ Food Safety Russian Sanitary Rules and Norms. GAIN Report \#RS2010. SanPiN-96. USDA Foreign Agricultural Service. Gossanepidnadzor Department of the Ministry of Public Health Care of Russia.

Georgian Food Safety Rules (2001). Fish, other river/sea products and products made from them. SanPiN-2.3.2.560-96. The Minister's Decree 16/08/2001 N301/n for Health, Labour and Social Affairs.

Öztekin, A., \& Bat, L. (2017). Microlitter pollution in sea water: A preliminary study from Sinop Sarikum coast of the southern Black Sea. Journal of Fisheries and Aquatic Sciences, 17:1431-1440. https://doi.org/10.4194/1303-2712-v17_6_37

Sivaci, E.R., Yardim, Ö., Gönülol, A., Bat, L., \& Gümüs, F. (2008). Sarıkum (Sinop-Türkiye) lagününün bentik algleri (Benthic algae of Sarkum (Sinop-Turkey) lagoon) Journal of FisheriesSciences.com. https://doi.org/10.3153/jfscom.2008022

TFC. 2009. Official Gazette of Republic of Turkey. Notifications changes to the maximum levels for certain contaminants in foodstuffs (in Turkish). (Notification No: 2009/22), Issue: 27143.

Yardim, Ö., Sendogan, E., Bat, L., Sezgin, M., \& Çulha, M. (2008). Sarıkum Gölü (Sinop) makrobentik Mollusca ve Crustacea faunas1 (Macrobenthic Mollusca and Crustacea fauna of Lake Sarıum, Sinop, Turkey). E.Ü. Su Ürünleri Dergisi (E.U. Journal of Fisheries \& Aquatic Sciences), 25 (4): 301-309.

Yardim, Ö. (2017). Study on Fish Species of Sarikum Lake in Sinop Province in the Black Sea Region. Journal of Anatolian Environmental \& Animal Sciences, 2 (3): 72-74. 


\section{Macrothink}

Yilmaz, C. (2005). Ecosystem of Sarıum Lake (Sinop). O.M.Ü. Fen Edeb. Fak., Turkey Symposium on Quantum 219-223. (in Turkish).

\section{Copyrights}

Copyright for this article is retained by the author(s), with first publication rights granted to the journal.

This is an open-access article distributed under the terms and conditions of the Creative Commons Attribution license (http://creativecommons.org/licenses/by/4.0/) 